\title{
Progression of eye disease over 15 years in a patient with mucopolysaccharidosis type VI on enzyme replacement therapy
}

\author{
Mohammad Waseem Sarfraz (i) , ${ }^{1}$ Martin Smith, ${ }^{2}$ Simon Jones, ${ }^{3}$ Jane Ashworth ${ }^{1}$
}

${ }^{1}$ Ophthalmology, Manchester Royal Eye Hospital, Manchester, UK

${ }^{2}$ Optometry, Martin Smith Opticians, Lincoln, Lincolnshire, UK

${ }^{3}$ Willink Metabolic Unit, Manchester University NHS Foundation Trust, Manchester, UK

\section{Correspondence to}

Dr Mohammad Waseem Sarfraz; waseem.sarfraz@doctors.org.uk

Accepted 19 January 2021

\section{DESCRIPTION}

We present a case report of a 24-year-old Caucasian man with mucopolysaccharidosis (MPS) type VI (Maroteaux-Lamy) who has documented progression of visual loss and corneal clouding over 18 years of follow-up. The MPSs are a group of inherited lysosomal storage disorders resulting from abnormalities in enzymes, which degrade glycosaminoglycans (GAGs), resulting in a variable phenotype including skeletal, neurological, cardiac and ocular manifestations. Corneal clouding is a prominent feature of several MPS subtypes (MPSI, MPSIII, MPSIV and MPSVI) and is thought to be progressive although this has not previously been well documented. Treatment for MPSVI includes weekly infusions of enzyme replacement therapy (ERT), which has been shown to improve the

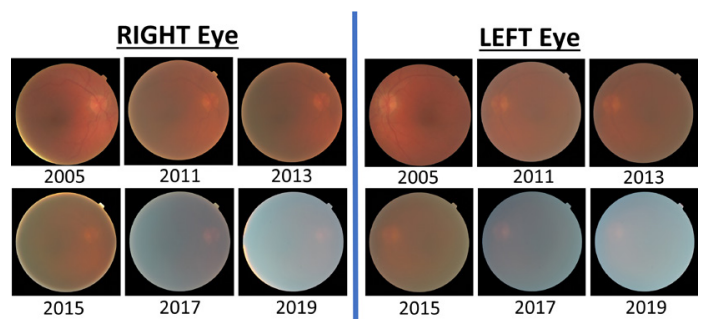

Figure 1 Serial colour retinal fundus photographs of both eyes over 15 years showing deteriorating clarity of view and increasing opacification (courtesy of Martin Smith Opticians).

\section{RIGHT Eye}
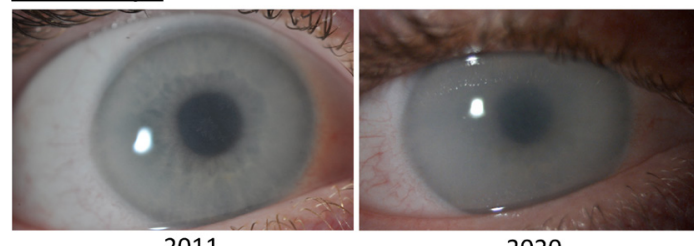

LEFT Eye

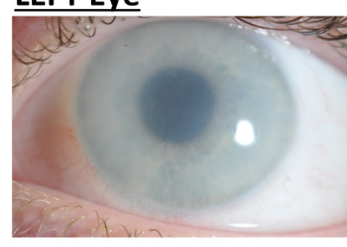

2011

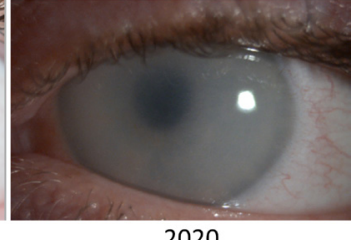

2020
Figure 2 External slit lamp images of both eyes from 2011 and 2020 showing increase in corneal clouding over time.

\section{Patient's perspective}

My vision had felt reasonably stable until around 2 years ago but since then, it has deteriorated and is more noticeable to me. It can vary from day to day, with some days being clear and others really hazy. This has affected how I use things in my daily life from the computer to riding my bike. I find any background light makes it hard to focus, and I have to sometimes screenshot things on my mobile phone and make them bigger to see them properly. I have to pay more attention when I'm out walking during the day because of the haziness and glare especially when crossing the road. I love to cycle, but now at times it can be difficult especially when I'm riding in and out of the shade. My mood is often affected by my vision. If I'm having a good day with my eyes, my mood tends to be better and the opposite if I'm not. I know surgery is always an option, but I understand there is always a risk of graft rejection after corneal transplant surgery. I hope there will one day be treatments developed to help improve my vision.

\section{Learning points}

- Mucopolysaccharidoses (MPSs) are a group of rare metabolic disorders that lead to both intracellular and extracellular deposition of glycosaminoglycans resulting in a wide range of systemic manifestations, including corneal clouding.

- Enzyme replacement therapy (ERT) can stabilise important systemic disease manifestations, but its effect on corneal clouding is not well known.

- This case report shows that corneal clouding and visual acuity continue to gradually deteriorate in a patient with MPSVI despite ERT treatment, providing further evidence that ERT is ineffective in treating corneal clouding in MPS.

systemic manifestations and quality of life, ${ }^{1}$ but effect on ocular findings is less clear.

This patient was diagnosed with MPSVI at age 6 in 2002, and a confirmed mutation was found in the ARSB gene, H430R/1482delC. His visual acuity (VA) was Snellen 6/9 (LogMAR 0.2) right eye and Snellen 6/6 (LogMAR 0.0) left eye at that time. He 
had mild corneal clouding $(1+)$ in both eyes. He was commenced on ERT in 2006. Over the course of the next 14 years, his vision gradually deteriorated, and in 2020, his VA was Snellen 6/18 (LogMAR 0.54) right eye and Snellen 6/15 (LogMAR 0.36) left eye with moderate corneal clouding $(2+)$ in both eyes. Refraction was +13.00 in both eyes, and central corneal thickness was increased at $767 \mu \mathrm{m}$ in the right eye and $825 \mu \mathrm{m}$ in the left. His serial retinal fundus photographs show deteriorating clarity of the image over the course of 14 years (figure 1). When reviewed with sequential external slit lamp images (figure 2), it is clear that this is due to worsening corneal clouding.

Corneal clouding occurs in MPS due to the accumulation of GAGs both intracellularly and extracellularly with subsequent disruption of the optically important arrangement of collagen fibrils. Previous studies have shown no deterioration in ocular findings in patients with MPSVI on ERT, with 6/7 patients on ERT showing no deterioration in visual function over 44 months. ${ }^{2}$ To our knowledge, this is the longest follow-up of a patient with MPS with objective documentation of deterioration in corneal clouding despite being on ERT. This case provides evidence that ERT alone does not prevent progression of corneal clouding over time in MPSVI and that alternative treatments need to be developed. At present, surgery such as penetrating keratoplasty or deep anterior lamellar keratoplasty is the only option for treatment of established corneal clouding in MPSVI.

Contributors MWS, SJ and JA have all reviewed the patient in relation to his clinical care in hospital with $\mathrm{SJ}$ and JA being primarily responsible for his specialist management. MS has reviewed the patient in the community and performed eye tests on him for over 15 years. All four authors have contributed to the manuscript through image acquisition, draft write-up and final revisions.

Funding The authors have not declared a specific grant for this research from any funding agency in the public, commercial or not-for-profit sectors.

Competing interests None declared.

Patient consent for publication Obtained.

Provenance and peer review Not commissioned; externally peer reviewed.

\section{ORCID iD}

Mohammad Waseem Sarfraz http://orcid.org/0000-0002-9230-0590

\section{REFERENCES}

1 Vairo F, Federhen A, Baldo G, et al. Diagnostic and treatment strategies in mucopolysaccharidosis VI. App/ Clin Genet 2015;8:245-55.

2 Pitz S, Ogun O, Arash L, et al. Does enzyme replacement therapy influence the ocular changes in type VI mucopolysaccharidosis? Graefes Arch Clin Exp Ophthalmol 2009:247:975-80.

3 Lampe C, Harmatz PR, Parini R, et al. Enzyme replacement therapy initiated in adulthood: findings from the mucopolysaccharidosis VI clinical surveillance program. Mol Genet Metab 2019;127:355-60.

Copyright 2021 BMJ Publishing Group. All rights reserved. For permission to reuse any of this content visit

https://www.bmj.com/company/products-services/rights-and-licensing/permissions/

BMJ Case Report Fellows may re-use this article for personal use and teaching without any further permission.

Become a Fellow of BMJ Case Reports today and you can:

- Submit as many cases as you like

- Enjoy fast sympathetic peer review and rapid publication of accepted articles

- Access all the published articles

Re-use any of the published material for personal use and teaching without further permission

Customer Service

If you have any further queries about your subscription, please contact our customer services team on +44 (0) 2071111105 or via email at support@bmj.com.

Visit casereports.bmj.com for more articles like this and to become a Fellow 